\title{
PEMBELAJARAN NILAI MORAL MELALUI KOMIK BERBASIS FLASH DIADAPTASI KEARIFAN BUDAYA NASIONAL
}

\author{
Muhlis Fajar Wicaksana \\ Tadris Bahasa Indonesia FITK IAIN Surakarta \\ wicaksana_muhlis@yahoo.com
}

\begin{abstract}
Abstrak
Penelitian ini bertujuan untuk mengetahui pengaruh penggunaan media pengajaran yang berbentuk komik berbasis Flash dengan mengoptimalkan kearifan budaya nasional. Penelitian ini termasuk penelitian eksperimen semu (quasi experiment). Hasil instrument tes dan nontes tersebut, kemudian dianalisis menggunakan analisis statistik parametrik (ujit). Hasil analisis data menunjukkan hasil rata-rata kelas yang diberi pengajaran nilai moral melalui media komik berbasis flash sebesar 84.31 sedangkan pada kelas kontrol 80,50. Dengan hasil tersebut selanjutnya dianalisis dengan uji t. Hasil uji hipotesis diperoleh pvalue sebesar 0.041 , sedangkan nilai t-tabel dengan taraf signifikan 5\%. Dengan hasil ini dapat dinyatakan bahwa terdapat pengaruh yang signifikan pengajaran nilai moral di SD Negeri 2 Sukoharjo melalui media komik berbasis flash. Hasil penelitian ini menunjukkan bahwa pengajaran nilai moral di SD Negeri 2 Sukoharjo melalui media pengajaran yang menarik dapat menarik motivasi siswa dalam belajar. Berkaitan dengan tanggapan mengenai media pengajaran yang dilakukan, dari enam siswa yang diwawancarai menunjukkan hasil yang positif (empat siswa menyatakan mendukung, dua siswa masih bingung). Hasil dari penelitian menyimpulkan bahwa adanya keseringan siswa menelaah karya sastra melalui media pengajaran yang menarik, siswa akan dapat menemukan nilainilai moral dalam sebuah cerita rakyat dan mengimplementasikan di kehidupannya seharihari.
\end{abstract}

Kata kunci : Pengajaran nilai moral, Komk berbasis flah, Kearifan budaya nasional

\begin{abstract}
This study aims to determine the effect of the use of instructional media in the form of Flash-based comics by optimizing national cultural wisdom. This study included quasi experimental research (quasi experiment). The results of the test instrument and the nontes were analyzed using parametric statistical analysis (t-test). The results of data analysis showed the average result of the class that was given the moral values through flash comic based media 84.31 while in the control class 80.50 . The result is then analyzed by $t$ test. Hypothesis test results obtained $\mathrm{p}$-value of 0.041 , while the value of $t$-table with a significant level of $5 \%$. With this result can be stated that there is a significant influence of teaching moral values in SD Negeri 2 Sukoharjo through flash-based comic media. The results of this study indicate that teaching moral values in SD Negeri 2 Sukoharjo through interesting teaching media can attract students' motivation in learning. With regard to responses on teaching media conducted, of the six students interviewed showed positive results (four students stated support, two students were still confused). The result of the research concludes that the existence of the students' frequency of studying the literary
\end{abstract}


works through interesting teaching media, the students will be able to find the moral values in a folklore and implement it in their daily life

Keywords: Teaching moral values, Flash-based comics, national cultural wisdom

\section{PENDAHULUAN}

Masa-masa sekarang ini kenakalan remaja telah menjadi penyakit ganas di tengah-tengah masyarakat, mengingat remaja merupakan bibit pemegang tampuk pemerintahan negara di masa depan. Lebih parah lagi, berbagai kasus kenakalan remaja tersinyalir telah meresahkan masyarakat, semisal kasus pencurian, kasus asusila seperti free sex, pemerkosaan, bahkan pembunuhan. Oleh karena itu, berbagai praktisi media, bahkan para pemerhati sosial dan pendidikan memprihatinkan hal tersebut.

Pendidikan moral kepada anak diawali saat mereka berada pada lingkungan keluarga terutama orang tua melalui proses sosialisasi norma dan aturan moral dalam keluarga sendiri serta lingkungan dekat pergaulan sosial anak. Kemudian saat anak masuk ke sekolah mulai diperkenalkan dan diajarkan sesuatu yang baru yang tidak diajarkan dalam keluarga. Sekolah adalah sebagai tempat sosialisasi kedua setelah keluarga serta tempat anak ditatapkan kepada kebiasaan dan cara hidup bersama yang lebih luas lingkupnya serta ada kemungkinan berbeda dengan kebiasaan dan cara hidup dalam keluarganya, sehingga berperan besar dalam menumbuhkan kesadaran moral diri anak.

Sekolah dasar (SD) merupakan satuan pendidikan yang menyelengarakan pendidikan enam tahun. Sekolah dasar merupakan bagian dari pendidikan dasar Sembilan tahun sebagaimana terdapat dalam PP nomor 28 tahun 1990 tentang pendidikan dasar. Dengan demikian sekolah dasar merupakan salah satu bentuk satuan pendidikan pada jenjang pendidikan dasar.

Pendidikan dasar memiliki peran dan tanggung jawab yang besar dalam menyikapi perkembangan aktual terhadap munculnya perilaku destruktif, anarkis dan radikalis. Untuk itu para pemangku pendidikan, terutama Kepala Sekolah, Guru, Pemimpin Perguruan Tinggi dan dosen harus memberikan perhatian dan pendampingan lebih besar kepada peserta didik dalam membentuk dan menumbuhkan 
pola pikir dan prilaku yang berbasis kasih sayang, toleran terhadap realitas keanekaragaman yang dibenarkan oleh peraturan dan perundangan.

Masa-masa sekarang ini kenakalan remaja telah menjadi penyakit ganas di tengah-tengah masyarakat, mengingat remaja merupakan bibit pemegang tampuk pemerintahan negara di masa depan. Lebih parah lagi, berbagai kasus kenakalan remaja tersinyalir telah meresahkan masyarakat, semisal kasus pencurian, kasus asusila seperti free sex, pemerkosaan, bahkan pembunuhan. Oleh karena itu, berbagai praktisi media, bahkan para pemerhati sosial dan pendidikan memprihatinkan hal tersebut.

Menurut, Emile Durkheim (dalam Soerjono Soekanto,1985:73), mengungkapkan bahwa sejatinya, kenakalan semacam itu normal terjadi pada diri remaja karena pada masa itu mereka sedang berada dalam masa transisi: anak menuju dewasa. Akan tetapi, perilaku menyimpang atau jahat kalau dalam batasbatas tertentu dianggap sebagai fakta sosial yang normal. Dalam batas-batas kenormalan tersebut tidak mungkin dihapusnya secara tuntas. Dengan demikian, perilaku dikatakan normal sejauh perilaku tersebut tidak menimbulkan keresahan dalam masyarakat, perilaku tersebut terjadi dalam batas-batas tertentu dan dilihat pada suatu perbuatan yang tidak disengaja.

Moral atau moralitas berarti hal mengenai kesusilaan (Burhanudin Salam, 2000:80). Sama halnya Huky (dalam Bambang Daroeso, 1986:22) mengatakan bahwa, kita dapat memahami moral dengan tiga cara, antaralain melalui; (1) Moral sebagai tingkah laku hidup manusia, yang mendasarkan diri pada kesadaraan, bahwa ia terikat oleh keharusan untuk mencapai yang baik sesuai dengan nilai dan norma yang berlaku dalam lingkungannya. (2) Moral sebagai perangkat ide-ide tentang tingkah laku hidup, dengan warna dasar tertentu yang dipegang oleh sekelompok manusia di dalam lingkungan tertentu.(3) Moral adalah ajaran tentang tingkah laku hidup yang baik berdasarkan pandangan hidup atau agama tertentu. Pengertian lain tentang moral berasal dari P. J. Bouman yang mengatakan bahwa "moral adalah suatu perbuatan atau tingkah laku manusia yang timbul karena adanya interaksi antara individu-individu di dalam pergaulan”. 
Moral sering dikaitkan dengan perbuatan, sikap, kewajiban, budi pekerti, susila, dan lain-lain. Franz Magnis Suseno (2000: 143) menyatakan bahwa moralitas merupakan kesesuaian sikap, perbuatan, dan norma hukum batiniah yang dipandang sebagai suatu kewajiban. Seorang tokoh dalam cerita dikatakan bermoral tinggi apabila ia mempunyai pertimbangan baik dan buruk. Namun, pada kenyataannya pandangan mengenai moral dalam hal-hal tertentu bersifat relatif.

Dengan demikian moral selalu berhubungan dengan nilai-nilai. Ciri khas yang menandai nilai moral yaitu tindakan manusia yang dilakukan secara sengaja, secara mau dan tahu; dan tindakan itu secara langsung berkenaan dengan nilai pribadi (person) manusia dan masyarakat Indonesia (Burhanudin Salam, 2000:74). Dapat ditarik simpulan bahwa, moral adalah keseluruhan norma yang mengatur tingkah laku manusia dalam masyarakat untuk melaksanakan perbuatan yang baik dan benar. Objek moral adalah tingkah laku manusia, perbuatan manusia, tindakan manusia, baik secara individual maupun secara kelompok.

Tidak lepas dari tugas sebagai seorang guru, guru harus bersedia bersinergis dengan orang tua anak didik untuk mewujudkan kehidupan moral yang baik dengan menggunakan konsep gold three angle yaitu kerjasama antara perguruan tinggi, pemerintah, dan penyandang dana. Mereka bisa bersinergis, khususnya pakar moral dapat memberi masukan pada pemerintah dan sekaligus terjun langsung ke masyarakat dengan langkah kongkrit untuk memperbaiki moral peserta didik (Kompas, 22 Maret 2007:12). Jadi nilai moral dibawa seorang guru yang meyakini kebenaran moral sebagai ideologi ideal dan harus ditanamkan pada setiap hati (personal, individu) agar suatu hari nanti kehidupan bangsa yang menjunjung nilainilai moral dapat terwujud.

Penanaman kebiasaan bersikap dan berbuat baik atau sebaliknya bersikap dan berbuat buruk, pada tahap awal pertumbuhannya, anak dapat sangat dipengaruhi oleh lingkungan sekolah tempat ia belajar. Peserta didik tidak begitu saja lahir sebagai pribadi bermoral atau berakhlak mulia. Lingkungan sekolah merupakan lembaga pendidikan yang dapat menunjang terjadinya rekonstruksi sosial ke arah masyarakat yang lebih baik, dan mengemban misi membentuk watak yang baik dari anak bangsa. 
Pendidikan harus dipahami sebagai bagian dari proses pembudayaan peserta didik sehingga bukan hanya pengalihan dan penguasaan ilmu pengetahuan serta pelatihan serta penguasaan keterampilan-keterampilan teknis tertentu, namun juga perlu dipahami sebagai penumbuhan dan pengembangan peserta didik menjadi pribadi manusia yang berbudaya dan beradab. Tujuan menjadi pribadi manusia yang berbudaya dan beradab adalah mewujudkan personal yang tidak hanya cerdas dalam segi kognitif akan tetapi mampu mengembangkan dan menanamkan kemampuan tertinggi dalam mengaktualisasikan budaya yang dimiliki suatu bangsa agar tidak kehilangan jati diri sebagai suatu bangsa akibat tergerus oleh perubahan zaman.

Suatu bangsa yang beradab, ketika melakukan semua hal, harus berpikir pada moral/ watak pada jati diri bangsa kita yang sesungguhnya. Dimensi moral erat kaitnnya dengan dimensi watak Pendek kata, krisis moral dapat diatasi dengan pembinaan watak. Dalam lingkup sekolah misalnya, pembinaan watak dapat diterapkan melalui pengajaran bahasa dan sastra Indonesia. Artinya, pengajaran sastra yang berdimensi moral. Tujuan dari penelitian ini adalah mengetahui pengaruh penggunaan media pengajaran yang berbentuk komik berbasis Flash dengan mengoptimalkan kearifan budaya nasional.

\section{METODE PENELITIAN}

Penelitian di lakukan pada bulan Juli 2014 hingga Januari 2015. Populasi yang diteliti adalah siswa kelas IV SD Negeri 2 Sukoharjo tahun pelajaran 2014/2015. Penarikan sampel menggunakan “Cluster Random Sampling”. Teknik pengambilan data dilakukan dengan pemberian tes dan observasi. Data belajar siswa diperoleh dari hasil tes yang diberikan kepada siswa setelah selesai proses pembelajaran.

Metode Penelitian pada penelitian ini adalah semu (Quasi Experimen) dipilihnya eksperimen semu karena keterbatasan mengontrol kelompok di luar proses pembelajaran. Disain yang digunakan dalam penelitian ini adalah Noneequivalent Control Group Design. Disain ini menggunakan kelompok yang memang sudah ada sebelumnya, seperti kelas. 
Kelompok eksperimen akan diberikan perlakuan berupa penerapan multmedia interaktif dalam pembelajaran Sedangkan kelompok kontrol akan diberikan pembelajaran konvensional. Selanjutnya kedua kelompok akan diberikan post test. Post test diberikan diakhir penelitian. Skor post test digunakan untuk menguji hipotesis dalam penelitian ini.

Uji validitas pada tes pengetahuan dilakukan untuk mengetahui kevalidan alat evaluasi. Hasil soal pengetahuan diuji coba kemudian dihitung daya beda soal, indeks kesukaran, validitas dan reliabilitas. Teknik analisis data pada penelitian ini terdiri dari uji prasyarat dan uji hipotesis. Pada uji prasyarat meliputi uji normalitas dan uji homogenitas. Uji normalitas menggunakan uji Kolmogorov Smirnov, sedangkan uji homogenitas dengan Levene test. Sedangkan pada uji hipotesis data penelitian menggunakan uji independent sample t-test.

\section{HASIL DAN PEMBAHASAN}

a. Hasil Penelitian

Adapun deskripsi data hasil penelitian dari kelas yang diberi pengajaran nilai moral melalui komik berbasis flash ditujukkan pada kelompok eksperimen dan kelas yang diberi metode konvensional yang ditujukkan pada kelompok kontrol sebagai berikut.

\section{Tabel 1. Deskripsi data}

\begin{tabular}{lcccccc}
\hline \multicolumn{1}{c}{ Kelompok } & N & Mean & St-dev & Max & Min & Median \\
\hline Eksperimen & 32 & 84,31 & 7,65 & 96 & 68 & 84 \\
Kontrol & 32 & 80,50 & 6,96 & 96 & 68 & 80 \\
\hline
\end{tabular}

Data hasil belajar nilai moral kelompok eksperimen dan kelompok kontrol, kemudian di analisis dengan uji hipotesis. Namun sebelum dilakukan analisis dengan uji hipotesis, terlebih dahulu data harus lolos. uji pra syarat. Uji pra syarat yang dimaksud adalah uji normalitas dan uji homogenitas.

Tabel 2. Hasil Uji prasyarat ; (a) Uji Normalitas dan (b) Uji Homogenitas 
a. Uji Normalitas

\begin{tabular}{|c|c|c|c|}
\hline Kelompok & p-value & Keputusan uji & Kesimpulan \\
\hline Eksperimen & 0,200 & $\mathrm{H}_{0}$ diterima & Normal \\
\hline Kontrol & 0,185 & $\mathrm{H}_{0}$ diterima & Normal \\
\hline \multicolumn{4}{|c|}{ b. Uji Homogenitas } \\
\hline Kelompok & p-value & Keputusan uji & Kesimpulan \\
\hline Eksperimen-kontrol & 0,529 & $\mathrm{H}_{0}$ diterima & Homogen \\
\hline
\end{tabular}

Berdasarkan tabel 2 hasil uji normalitas menggunakan analisis SPSS di atas menunjukkan bahwa data pada kelompok eksperimen dan kontrol berdistribusi normal. Sedangkan uji homogenitas kedu kelompok menunjukkan bahwa data tersebut homogen. Setelah data lolos uji pra syarat, maka dilanjutkan dengan analisis data, yaitu uji hipotesis dengan uji t.

Pada analisis SPSS uji t-test menunjukkan p-value sebesar 0,041<0,05. Hal ini menunjukkan keputusan uji t-test bahwa $\mathrm{H}_{0}$ ditolak maka ada pengaruh media komik berbasis flash diadaptasi kearifan budaya nasional terhadap pengajaran nilai moral.

b. Pembahasan

Karya sastra yang baik senantiasa menawarkan pesan moral yang berhubungan dengan sifat-sifat luhur kemanusiaan, memperjuangkan hak dan martabat manusia. Sifat-sifat luhur kemanusiaan tersebut pada hakikatnya bersifat universal. Artinya, sifat-sifat itu dimiliki dan diyakini kebenarannya oleh manusia. Hal inilah yang menjadi asumsi dasar bahwa dalam karya sastra, dalam hal ini cerita rakyat, terkandung nilai pendidikan moral. Nilai-nilai pendidikan moral ini perlu digali dan ditanamkan kepada pada pembaca, terutama kepada generasi penerus bangsa.

Pendidikan moral harus direncanakan secara matang oleh stakeholders, baik para pakar Pendidikan moral seperti rohaniawan (tokoh agama), pemimpin non formal (tokoh masyarakat), kepala sekolah, guru-guru, orang tua. Pendidikan moral ini harus memperhatikan nilai-nilai secara holistik dan uiniversal. Keberhasilan pendidikan moral ditandai dengan menghasilkan 
peserta didik yang memiliki kompetensi personal dan kompetensi sosial yang memiliki moral.

Moral atau moralitas berarti hal mengenai kesusilaan (Burhanudin Salam, 2000: 80). Sama halnya Huky (dalam Bambang Daroeso, 1986: 22) mengatakan bahwa, kita dapat memahami moral dengan tiga cara, antaralain melalui; (a) moral sebagai tingkah laku hidup manusia, yang mendasarkan diri pada kesadaraan, bahwa ia terikat oleh keharusan untuk mencapai yang baik sesuai dengan nilai dan norma yang berlaku dalam lingkungannya; (b) moral sebagai perangkat ide-ide tentang tingkah laku hidup, dengan warna dasar tertentu yang dipegang oleh sekelompok manusia di dalam lingkungan tertentu; (c) moral adalah ajaran tentang tingkah laku hidup yang baik berdasarkan pandangan hidup atau agama tertentu. Pengertian lain tentang moral berasal dari P. J. Bouman yang mengatakan bahwa "moral adalah suatu perbuatan atau tingkah laku manusia yang timbul karena adanya interaksi antara individu-individu di dalam pergaulan".

Dengan demikian moral selalu berhubungan dengan nilai-nilai. Ciri khas yang menandai nilai moral yaitu tindakan manusia yang dilakukan secara sengaja, secara mau dan tahu; dan tindakan itu secara langsung berkenaan dengan nilai pribadi (person) manusia dan masyarakat Indonesia (Burhanudin Salam, 2000:74). Dapat ditarik simpulan bahwa, moral adalah keseluruhan norma yang mengatur tingkah laku manusia dalam masyarakat untuk melaksanakan perbuatan yang baik dan benar. Objek moral adalah tingkah laku manusia, perbuatan manusia, tindakan manusia, baik secara individual maupun secara kelompok.

Berdasarkan media pembelajaran yang digunakan penelitian didapat nilainilai yang terdapat pada cerita telaga sarangan yang dipakai sebagai bentuk pembelajaran SD, dapat diuraikan sebagai berikut;

Nilai moral pada mitos bahwa Djoko Linglung melihat bahwa kedua orang tuanya berubah menjadi ular dan ingin membuat genangan air sebanyakbanyaknya untuk menenggelamkan gunung Lawu. Mengetahui niat jahat kedua orang tuanya itu, Djoko Linglung bersemedi agar orang tuanya tidak meneruskan 
niat jahatnya untuk menenggelamkan gunung Lawu dan Djoko Linglung pun berhasil menyadarkan kedua orang tuanya. Seorang anak mengingatkan dan mendoakan orang tuanya yang menyimpang dan berniat jahat akan merugikan orang banyak dan orang tuanya pun insyaf bahwa niatnya itu buruk. Inilah salah satu nilai moral yang terdapat dalam cerita telaga sarangan,

Masih ada pula Nilai moral yang lain, antara lain adalah sifat kesombongan, Kyai Pasir dan Nyai Pasir ketika berubah menjadi ular besar dan merasa memiliki kekuatan, mereka ingin menenggelamkan Gunung Lawu. Berawal dari sikap seperti inilah yang dinamakan sikam sombong atau congkak. Dalam berkehidupan sebaiknya walaupun kita sudah memiliki semuanya di dunia ini, kita harus tetap jangan menunjukkan sikap kita yang sombong, congkak, ataupun malah merasa dirinya sebgai penguasa. Kemudian bertindak secara semena-mena terhadap orang yang lebih lemah dibandingkan kita.

Selain itu nilai moral yang dapat kita petik dari cerita telaga sarangan ini adalah kegigihan atau usaha dari Kyai Pasir dan Nyai Pasir yang begitu kuat. Kyai Pasir dan Nyai Pasir ini mempunyai usaha yang begitu gigih. Hal ini terlihat ketika mereka berdua mempunyai keinginan untuk memiliki seorang anak, mereka berdoa, bersemedi supaya diberi pentunjuk dari Sang Hyang Widhi, dan ternyata dari kegigihannya berdoa, bersemedi, keinginan mereka berdua dikabulkan. Begitu juga dengan kegigihan si anak, yang mendoakan orang uanya supaya dapat sadar dan berubah akan kesalahan-kesalahan yang telah dilakukannya. Dapat kita resapi bahwa usaha seperti inilah yang harus kita teladani bersama. Dalam menjalani kehidupan ini, selain kita berusaha dengan tekun, gigih, dan semangat tinggi, kita tidak lupa pula untuk berdoa kepada sang pencipta kita. Adapun kebiasaan tata cara kita berhubungan dengan sang pencipta sudah diatur di setiap agama atau kepercayaan yang masing-masing kita anut.

Bila cerita zaman dahulu dikaitkan dengan masa sekarang ini memang berbeda. Zaman-zaman dahulu memang lebih mempercayai pada kekuatan alam atau panggilan alam ataupun bisikan alam. Tanpa berpikir secara logika. Hal ini tidak dapat diterima dengan akal sehat bila dirasakan dengan sungguh-sungguh. 
Berbeda dengan zaman sekarang ini, kita sudah dapat memulai untuk berpikir yang dapat diterima oleh akal sehat. Bukan malah percaya pada hal-hal yang belum tentu kebenarannnya. Apalagi jika hal itu tidak dapat diterima oleh akal sehat. Hal ini terlihat ketika Kyai Pasir ingin mendapatkan kekuatan, awet muda, dan dapat mengalahkan semua binatang buas yang ada di hutan. Kyai pasir ini percaya bahwa telur yang dia dapat dari ladangnya (dari bersemedi) dapat memberikan semua hal yang diinginkan. Tetapi apa yang didapat? Ternyata telur itu adalah telur ular, yang mana ketika dimakan akan berdampak pada yang memakannnya, mulai dari gatal-gatal, badannya terasa panas, dan sampai yang terakhir berubah menjadi ular jelmaan. Hal inilah yang memberikan pelajaran pada kita untuk lebih berpikir secara rasional, bukan berpikir secara irasional. Itulah beberapa hal nilai moral yang dapat kita petik dari cerita telaga sarangan tersebut. Kita dapat mengambil hikmahnya dari cerita tersebut untuk kepentingan kita mengarungi hidup ini dalam bermasyarakat, berbangsa, dan bernegara.

Berdasarkan hasil analisis siswa SD diberi pengajaran nilai moral melalui komik berbasis flash yang diadaptasi kearifan budaya nasional memberikan pengaruh yang signifikan terhadap pengajaran nilai moral. Pada hasil tes menunjukkan siswa SD dapat memecahkan masalah dengan mengambil hikmah dari cerita rakyat tersebut. Siswa SD yang diberi pengajaran nilai moral melalui komik berbasis flash yang diadaptasi kearifan budaya nasional lebih menikmati belajar sambil bermain.

Salah satu bentuk pengajaran sastra dapat dilakukan melalui komik yang berbasis flash. Pada dasarnya komik adalah Komik adalah Media untuk bercerita dan sebagai media hiburan yang murah meriah dengan tujuan untuk menghibur pembacanya, namun bukan hanya sebagai media untuk menghibur saja, komik juga dapat digunakan sebagai media untuk mendidik. (Arsyad Maidar, 1994: 14).

Adapun menurut Sri Anittah (2008: 78) Komik adalah suatu kartun yang mengungkapkan suatu karakter dan memerankan suatu cerita dalam urutan yang erat dihubungkan dengan gambar dan dirancang untuk memberi hiburan kepada 
pembaca. Komik merupakan suatu bentuk cerita bergambar yang terdiri atas berbagai situasi cerita bersambung, kadang bersifat humor.

Lubis (dalam Soeparno, 1988: 67) memaparkan komik adalah "Media komunikasi Alternatif", komik dianggap sebagai salah satu media komunikasi yang identik dengan gambar meskipun komik memberi kesempatan berekspresi secara verbal dan visual akan tetapi sebagai media seni. komik tetap berada dalam batas-batas komunikasi. Komik juga diartikan sebagai bentukan dari; tujuan komersial-ekonomis yang berusaha memenuhi kebutuhan pembaca akan hiburan, informasi, dan pendidikan. Tujuannya hanya dapat berhasil apabila persyaratan produksi, distribusi, persepsi, dsn kemungkinan pengaruhnya dihubungkan satu sama lain.

Sejalan dengan hasil penelitian Matt Elbeck dan B. Jean Mandernach yang berjudul Journals for Computer-Mediated Learning: Publications of Value for the Online Educator (2009), mengungkapkan bahawa dengan media computer siswa akan lebih berkembang dan membutuhkan biaya lebih banyak daripada pengajaran dengan ceramah. Pada penelitian ini, media yang digunakan disajikan dalam bentuk animasi yang dapat mengembangkan daya imajinasi siswa dalam mengembangkan materi pelajaran kimia. Tetapi pada penelitian ini juga membutuhkan biaya dan waktu persiapan yang lama.

Pada hasil wawancara dapat diketahui bahwa pengaruh guru kelas SD terhadap penggunaan media pengajaran berbentuk komik berbasis flash dengan mengadaptasikan kearifan budaya, diperoleh data sebagai berikut. Dari pertanyaan pertama diperoleh jawaban bahwa empat siswa menyatakan tertarik untuk menyimak materi yang disampaikan melalui media komik berbasis flash, sedangkan dua siswa lainnya menyatakan sebaliknya. Empat siswa yang diwawancarai menyatakan tertarik mengikuti pengajaran di SD ini, karena mereka merasa mudah dalam menuangkan memahami materi yang disampaiakan melalui cerita komik tersebut. Dua siswa yang diwawancarai merasa tidak suka dengan pengajaran nilai moral melalui komik flash tersebut, karena mereka sulit untuk memahami alur cerita dari komik tersebut, sehingga 
menimbulkan perasaan yang tidak enjoy dalam menyimak jalannnya cerita tersebut.

Dari keenam siswa, siswa tersebut kesemuanya mengarah pada harapan untuk dikembangkannya media pengajaran tersebutlebih kedalam semua materi pelajaran, bukan hanya dalam materi pelajaran bahasa Indonesia saja, khususnya pengajaran menyimak sastra, melainkan pada materi ilmu pengetahuan sosial, ilmu pengetahuan alam ataupun yang lain yang sifatnya teori-teori.

\section{SIMPULAN}

Berdasarkan hasil analisis dan pembahasan dapat diuraikan bahwa terdapat pengaruh yang signifikan pengajaran nilai moral melalui komik berbasis flash yang diadaptasi kearifan budaya nasional. Hasil penelitian dengan uji-t menunjukan bahwa terdapat perbedaan yang signifikan hasil belajar siswa yang belajar melalui media komik berbasis flash dengan siswa yang belajar melalui pembelajaran konvensional. Hal tersebut terbukti dengan hasil perhitungan uji t-test melalui SPSS diperoleh $\mathrm{p}$-value sebesar 0,041 dengan taraf signifikan $5 \%$ sehingga pvalue $<0,05$, ini berarti $\mathrm{H}_{0}$ ditolak dan $\mathrm{H}_{\mathrm{a}}$ diterima, dan diperolehan nilai ratarata hasil belajar kelas ekspereimen lebih tinggi dari kelas control yaitu sebesar $84,31>80,50$.

Hal ini menunjukkan pengajaran nilai moral melalui media pengajaran yang menarik diharapkan siswa dapat menemukan-menemukan nilai-nilai moral dalam cerita rakyat. Cerita rakyat ini sangat berarti bagi guru kelas SD untuk mengajarkan nilai-nilai moral yang akan dimplementasikan melalui perilaku kesehariannya.

Manajemen waktu yang baik dan persiapan dalam pembelajaran pada penerapan media pembelajaran yang digunakan, khususnya metode resitasi dan eksperimen akan memberikan dampak positif terhadap belajar pada aspek pengetahuan, sikap, dan keterampilan. Peningkatan kualitas pembelajaran harus selalu dilakukan oleh guru, dengan menerapkan metode pembelajaran yang bervariasi dalam proses belajar mengajar sehingga siswa menjadi termotivasi dalam mengikuti pembelajaran. 
Bagi dosen, hendaknya berperan aktif sebagai inovator dan fasilitator sehingga mampu memilih pendekatan, strategi, teknik, dan bahan ajar yang tepat dan kreatif bagi guru kelas SD. Bagi guru kelas SD, dapat dijadikan sebuah petunjuk untuk melakukan pengajaran sastra yang lebih menrik lagi dari pengembangan cerita telaga sarangan tersebut.

Hasil penelitian ini dapat digunakan sebagai acuan untuk penelitianpenelitian berikutnya yang sejenis dan diharapkan dapat memberikan kontribusi bagi perkembangan pengajaran nilai moral yang harus ditanamkan pada siswa.

\section{REFERENSI}

Aminuddin. 2000. Pengantar Apresiasi Sastra. Bandung: Sinar Baru.

B. Rahmanto. 1988. Metode Pengajaran Sastra Pegangan Guru Mengajar Sastra Yogyakarta: Kanisius.

Burhanuddin Salam.1997. Logika Material Filsafat; Ilmu Pengetahuan Filsafat. Jakarta: Penerbit Rineka Cipta

Frans Magnis Suseno. 1986. Kuasa dan Moral. Jakarta: PT Gramedia.

Henri Guntur Tarigan. 2008. Menyimak Sebagai Suatu Keterampilan Berbahasa. Bandung: Angkasa Bandung.

Jabrohim (ed), 2001. Metodologi Penelitian Sastra. Yogyakarta: Hanindita Graha Widya Angkasa.

Matt Elbeck and B. Jean Mandernach. 2009. Journals for Computer-Mediated Learning: Publications of Value for the Online Educator. USA : Troy University

Mulyasa. 2004. Kurikulum Berbasis Kompetensi. Bandung: Rosda Karya.

Soerjono Soekanto. 1985. Sosiologi Suatu Pengantar. Jakarta: CV Rajawali.

Soeparno. 1988. Media Pengajaran Bahasa. Yogyakarta: PT Intan Pariwara.

Sri Anittah. 2008. Media Pembelajaran. Surakarta: UNS Press.

Sugiyono. 2011. Metode Penelitian Pendidikan. Bandung: Alfabeta

Sujana \& Ahmad Rivai. 2005. Media Pengajaran. Bandung : Penerbit Sinar Baru Algensindo 
2008. Metode Penelitian Pendidikan. Bandung : PT Remaja Rosdakarya.

Victor Purba, "VI Siap Melangkah Lebih Kongkrit", Kompas, Jakarta, 23 Maret 2007. 